\title{
KONSEP DHANB DAN ITHM DALAM ALQURAN (Studi Kajian Semantik Alquran)
}

\author{
Dini Hasinatu Sa'adah, M.Solahudin, Dadang Darmawan \\ Fakultas Ushuluddin UIN Sunan Gunung Djati Bandung \\ Jl.A.H.Nasution 105 Cibiru Bandung 40614, Indonesia \\ E-Mail : sartikaela27@gmail.com
}

In the Qur'an there are several terms that indicate the meaning of sin, such as Dhanb, Ithm, JarmAndJunah. From some term meaning sin, the author focuses only on the word Dhanb andthm, because on the one hand, when viewed from an oral al-Arab dictionary, the word Dhanb is synonymous with Ithm, which means the synonym of the word. But on the other hand, when viewed from the interpretation of IbnKathir and the al-Maraghi commentary the word Dhanb and Ithm is different in meaning, which Dhanbshows sin for the heathen, whileIthmshows sin for the hypocrites. Therefore, the author seeks to examine the meaning of the word DhanbandIthm with semantic approach. Based on the contradictions mentioned above, then in this research is to know the meaning of the word Dhanb and Ithmin the Qur'an with semantic approach. The research method used is semantic method. This method is used to understand the various terms or key words used in a commentary. Then this research is qualitative, which is in the form of library research (library research) with reference to two source that is primary and secondary.

As for result of analysis about meaning of word Dhanb and Ithm in al-Qur'an by using semantic approach, writer can conclude that the basic meaning of the word Dhanb is a sin or a mistake, and its relational meaning Dhanb is the sin of the infidels in which they are the ones who reject the verses of Allah and deny the verses of Allah. While the basic meaning of Ithm is unlawful deed, and the relational meaning Ithm is the sin of the hypocrites who they claim to believe in his mouth, but in theirhearts and deeds do not reflect that they are believers.

Keywords:

Semantic; Dhanb; Ithm.

\begin{abstract}
Abstrak
Dalam al-Qur'an ada beberapa term yang menunjukkan makna dosa, diantaranya yaitu dhanb, ithm, jarm dan junah. Dari beberapa term yang bermaknadosa, penulis hanya terfokuskan kepada kata dhanb dan ithm, karena di satusisi, bila di lihat dari kamus lisan al-Arab, kata dhanb itu bersinonim dengan ithm, yang mana berarti adanya sinonimitas pada kata itu. Namun di sisilain, bila di lihat dari tafsir Ibn Katsir dan tafsir al-Maraghi kata dhanb dan ithm itu berbeda maknanya, yang mana dhanb itu menunjukkan dosa bagi orang kafir, sedangkan ithm menunjukkan dosa bagi orang munafiq. Maka dari itu,penulis berusaha untuk meneliti makna kata dhanb dan ithm dengan pendekatan semantik. Berdasarkan adanya kontradiksi yang disebutkan di atas, maka pada penelitian ini adalah untuk mengetahui makna kata Dhanb dan ithm dalam al-Qur'an dengan pendekatan semantik. Metode penelitian yang digunakan adalah metode semantik. Metode ini digunakan untuk memahami berbagai istilah atau kata-kata kunci yang digunakan pada sebuah tafsir. Kemudian penelitian ini bersifat kualitatif, yang berbentuk library research (penelitian kepustakaan) dengan merujuk pada dua sumber yaitu primer dan sekunder. Adapun hasil analisis tentang makna kata dhanb dan ithm dalam Alquran dengan menggunakan pendekatan semantik, penulis dapat menyimpulkan bahwa makna dasar kata dhanb adalah dosa atau kesalahan, dan makna relasionalnya dhanb adalah dosa orang kafir yang mana mereka adalah orang-orang yang menolak pada ayat-ayat Allah dan mendustakan ayat-ayat Allah. Sedangkan makna dasar ithm adalah perbuatan yang tidak halal, dan makna relasional ithm ialah dosanya orang munafiq yang mana mereka mengaku beriman pada mulutnya, tetapi dalam hati dan perbuatan mereka tidak mencerminkan bahwa mereka adalah orang yang beriman.
\end{abstract}

Kata Kunci:

Semantik; Dhanb; Ithm. 
Dini Hasinatu Sa'adah, M.Solahudin, Dadang Darmawan

\section{A. PENDAHULUAN}

Alquran al-karim ialah mukjizat Islam yang kekal dan mukjizatnya itu selalu diperkuat oleh kemajuannya ilmu pengetahuan. Alquran diturunkan Allah kepada Rasulullah, Muhammad SAW untuk mengeluarkan manusia dari suasana yang gelap menuju suasana yang terang, dan dapat membimbing mereka ke jalan yang lurus. Rasulullah SAW. menyampaikanAlquran itu kepada para sahabat-sahabatnya, kemudian kepada orang Arab asli, sehingga mereka bisa memahaminya itu berdasarkan naluri mereka masing-masing. Ketika mereka mengalami ketidakfahaman dalam memahami suatu ayat, maka mereka menanyakan langsung kepada Rasulullah SAW. ${ }^{1}$

Berkenaan dengan Alqur'an, Alquran memberikan berbagai ilmu pengetahuan kepada manusia, memberikan berbagai solusi kepadanyaketika sedang kesulitan, buntu, dan lain sebagainya, karena Alquran selalu memberikan petunjuk yang terbaik untuk manusia. Ada banyak sekali pembahasan yang Alquran jelaskan, salah satunya ialah mengenai dosa, Alquran menyebutkan dosa dari mulai macam-macam dosa, meminta ampunan dari dosa dan lain sebagainya.

Dosa adalah perbuatan yang melanggar hukum Allah, yang mana berarti Allah sudah menetapkan sesuatu apa yang harus dilakukan dan apa yang harus ditinggalkan. Ketika seseorang melanggar apa yang sudah Allah tetapkan untuk ditinggalkan atau dijauhi, maka itu termasuk ke dalam kategori dosa, tetapi bila seseorang tersebut patuh terhadap apa yang Allah perintahkan dan meninggalkan apa yang Allah larang, maka itu termasuk ke dalam kategori ketaatan.

Penulis awalnya tertarik untuk meneliti tentang dosa, karena setiap manusia pasti melakukan perbuatan dosa, dan terkadang melakukan sesuatu yang menjadikannya lupa bahwa perbuatan yang dilakukan itu termasuk dosa. Maka menurut penulis, meneliti tentang

${ }^{1}$ Manna Khalil al-Qattan, Studi Ilmu-ilmu Qur'an, (Bogor:Pustaka Litera AntarNusa, 2012), 1.
Konsep Dhanb dan Ithm dalam Alquran (Studi Kajian Semantik Alquran)

dosa itu sangatlah penting untuk dikaji, agar manusia lebih berhati-hati dalam berprilaku.

Dalam Alquran ada beberapa term yang menunjukkan makna dosa, diantaranya yaitu dhanb, ithm, jarm dan junah. Namun, ada beberapa penempatan yang Allah sandingkan dengan lafadz-lafadz tersebut, yang berarti Alquran menjelaskan bahwa ada beberapa perbedaan dalam memaknai dosa ini.

Dari beberapa term yang bermakna dosa, penulis hanya terfokuskan kepada kata dhanb dan ithm. Karena di satu sisi, bila di lihat dari kamus lisan al-Arab, kata dhanb itu bersinonim dengan ithm. ${ }^{2}$ yang mana berarti adanya sinonimitas pada kata itu. Namun di sisi lain, bila di lihat dari tafsir Ibn Katsir dan tafsir al-Maraghi kata dhanb dan ithm itu berbeda makna nya, yang mana dhanb itu menunjukkan dosa bagi orang kafir yang mana mereka menolak pada ayat-ayat Allah,sedangkanithm menunjukkan dosa bagi orang beriman yangmunafik, yang mana hanya dimulutnya saja seseorang tersebut beriman, namun pada perbuatannya jauh dari keimanan.

Maka dari itu, penulis berusaha untuk meneliti makna kata dhanb dan ithm, karena ternyata dalam penafsiran Alquran dan dari kamus lisan al-Arab itu berbeda pemaknaan, sehingga penulis akan meneliti kata dhanbdan ithm dengan pendekatan semantik. Maka penulis memberikan judul penelitian ini dengan "Kajian Semantik Makna Kata Dhanb dan Ithm dalam Alquran.

Dalam Alquran kata Dhanb muncul 37 kali, ada yang berbentuk mufrad yaitu sebanyak 11 kali, dan ada juga yang berbentuk jamak sebanyak 26 kali, tersebar dalam 26 surat pada 37 ayat, 17 surat ada pada surat Makiyyah dan 9 surat ada pada surat Madaniyyah. ${ }^{3}$

Dari beberapa ayat yang menunjukkan lafadz-lafadz Dhanb dan Ithm dalam Alquran,

\footnotetext{
${ }^{2}$ Al-Allamah Abi al-Fadhl Jamaluddin Muhammad bin Mukarram ibn Mandzur al-Ifriqi alMishri, Lisan al-Arab, (Beirut: Daar as-Shadir, 1355 ), jilid I, 389 dan jilid 12, 5.

${ }^{3}$ Berdasarkan penelitian dari al-Qur'an al-Hadi karya Ahmad Luthfi Fathullah.
} 
Dini Hasinatu Sa'adah, M.Solahudin, Dadang Darmawan
Konsep Dhanb dan Ithm dalam Alquran (Studi Kajian Semantik Alquran) maka tujuan pada penelitian ini adalah untuk mengungkap makna kata dhanb dan ithm dalam Alquran dengan pendekatan semantik.

Mengenai semantik, semantik itu mula nya berasal dari bahasa Yunani, mengandung makna to signify atau memakai. Sebagai istilah teknis semantiknya yaitu mengandung arti"studi tentang makna". Yang mana dengan anggapan bahwa makna menjadi bagian dari bahasa, maka semantikmerupakan bagian dari linguistik. $^{4}$

Di masa sekarang ini ada beberapa metode dan pendekatan dari berbagai disiplin ilmu yang berkembang dalam menafsirkan Alquran, yang membuktikan variasi makna yang terkandung dalam Alquran, salah satunya ialah memahami kandungan makna ayat Alquran dengan pendekatan teori semantik. Semantik yang digunakan ialah semantik dari teorinya Toshihiko Izutsu.

Menurut Toshihiko Izutsu Semantik Alquran ialah kajian analitik terhadap istilahistilah kunci suatu bahasa dengan suatu pandangan yang akhirnya sampai pada konsep weltanschauung atau pandangan dunia masyarakat yang menggunakan bahasa itu, tidak hanya sebagai alat bicara dan berfikir, tetapi yang lebih penting lagi pengkonsepan dan penafsiran dunia yang melingkupinya. ${ }^{5}$

\section{B. HASIL DAN PEMBAHASAN \\ 1. Pengertian Kata Dhanb dan Ithm}

Kata Dhanb dalam bahasa Arab artinya ialah dosa atau kesalahan. ${ }^{6}$ Dalam kitab lisan al-Arab dijelaskan bahwa makna dhanb sama dengan ithm, jarh, ma'shiat, dan jamaknya adalah dhunub. ${ }^{7}$ Sedangkan makna ithmialah perbuatan yang tidak halal. ${ }^{8}$ Dan dalam kitab

\footnotetext{
${ }^{4}$ Aminuddin, Semantik Pengantar Studi Tentang Makna, (Bandung: Sinar Baru Algensindo, 2015), 15.

5 Toshihiko Izutsu, Relasi Tuhan dan Manusia, (Yogyakarta: PT Tiara Wacana Yogya, 2003), 3.

${ }^{6}$ Ahmad Warson Munawwir, Kamus al-Munawwir Arab-Indonesia Terlengkap,(Surabaya: Penerbit Pustaka Progressif, 1997), 452.

${ }^{7}$ Al-Allamah Abi al-Fadhl Jamaluddin Muhammad bin Mukarram Ibn Mandzur al-Ifriqi al-Mishri, Lisan alArab,jilid 1, 389.

${ }^{8}$ Ahmad Warson Munawwir, al-Munawwir , 8.
}

Lisan al-Arab makna Ithm adalah Dhanb, ${ }^{9}$ yang mana berati adanya sinonimitas.

\section{Identifikasi Ayat-Ayat Yang Terdapat Kata Dhanbdan Ithm dalam Alquran \\ a. Kata Dhanb}

Berkenaan dengan Ayat-ayat tentang Dhanb, yang sudah ditemukan dari hasil pencarian di program digital al-Qur'an al-Hadi sebanyak 31 kali, ada yang berbentuk mufrad yaitu sebanyak 11 kali, dan ada juga yang berbentuk jamak sebanyak 23 kali, tersebar dalam 26 surat pada 37 ayat, 17 surat ada pada surat Makiyyah dan 9 surat ada pada surat Madaniyyah.

dalam Mu'jam Mufahrashkata dhanbmuncul sebanyak 39 dengan berbagai ذنب-ذنبك- derivasinya, yang terdiri dari kata

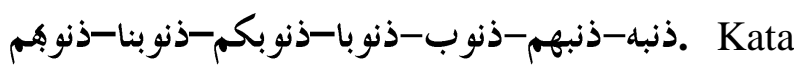
dhanbmuncul tiga kali, yaitu dalam Q.S asSyu'ara [26]: 14, Q.S Ghafir [40]:3, Q.S atTakwir [81]:9, kata dhanbiki-dhanbika muncul empat kali, yaitu dalam Q.S Yusuf [12]:29, Q.S al-Mu'min [40]:55, Q.S Muhammad [47]:19, Q.S al-Fath [48]:2, kata dhanbihi muncul dua kali, yaitu dalam Q.S al'Ankabut [40]:39, Q.S al-Rahman [55]:39, kata dhanbihim muncul dua kali, yaitu dalam Q.S al-Mulk [67]:11, Q.S al-Shams [91]:14, kata dhunub muncul lima kali, yaitu dalam Q.S Ali Imran [3]:135, Q.S al-Isra' [17]:17, Q.S al-Furqan [25]:58, al-Zumar [39]:53, alDzariyat [51]:59, kata dhunuban muncul satu kali, yaitu dalam Q.S al-Dzariyat [51]:59, kata dhunubakum muncul tujuh kali, yaitu dalam Q.S Ali Imran [3]:31, Q.S al-Ma'idah [5]:18, Q.S Ibrahim [14]:10. Q.S al-Ahzab [33]:71, Q.S al-Ahqaf [46]:31, Q.S al-Saff [61]:12, Q.S Nuh [71]:4, kata dhunubana muncul lima kali, yaitu dalam Q.S Ali Imran [3]:16, Q.S Ali Imran [3]:193, Q.S Yusuf [12]:97, Q.S Ghafir [40]:11, kata dhunubihim muncul 10 kali, yaitu dalam Q.S Ali Imran [3]:11, Q.S Ali Imran [3]:135, Q.S al-Maidah [5]:49, Q.S alAn'am [6]:6, Q.S al-A'raf [7]:100, Q.S alAnfal [8]:52, Q.S al-Anfal [8]:54, Q.S at-

\footnotetext{
${ }^{9}$ Al-Allamah Abi al-Fadhl Jamaluddin Muhammad bin Mukarram Ibn Mandzur al-Ifriqi alMishri, Lisan al-Arab, jilid 12, 5.
} 
Dini Hasinatu Sa’adah, M.Solahudin, Dadang Darmawan
Konsep Dhanb dan Ithm dalam Alquran (Studi Kajian Semantik Alquran)
Taubah [9]:102, Q.S al-Qassas [28]:78, Q.S Ghafir [40]:21. ${ }^{10}$

\section{b. Lafadz Ithm}

Kata Ithmdalam al-Qur'an muncul 32 kali dengan variasi yang berbeda-beda, ada yang berbentuk lafadz ithmun yaitu terdapat pada 29 ayat, lafadz ithman terdapat pada 9 ayat, kemudian lafadz athimun terdapat pada 1 ayat, athiman 1 ayat, dan athimin terdapat pada 1 ayat.

Sedangkan dalam Mu'jam Mufahrash muncul 40 kali dengan berbagai derivasinya, إثم - اثثا - اثيم - اثيما - آثم - Kata Ithm muncul 21 kali, yaitu dalam Q.S al-Maidah [5]:3, Q.S al-Maidah [5]:62, Q.S al-Maidah [5]:63, Q.S al-An'am [6]:120, Q.S al-An'am [6]:120, Q.S al-A'raf [7]:33, Q.S al-Nur [24]:11, Q.S al-Shura [42]:37, Q.S al-Hujurat [49]:12, Q.S al-Najm [53]:32, Q.S al-Mujadilah [58]:8, Q.S alMujadalah [58]:9, Q.S al-Baqarah [2]:85, Q.S al-Baqarah [2]:173, Q.S al-Baqarah [2]:182, Q.S al-Baqarah [2]:188, Q.S al-Baqarah [2]:203, Q.S al-Baqarah [2]:203, Q.S alBaqarah [2]:206, Q.S al-Baqarah [2]:219, Q.S al-Maidah [5]:2.

Kemudian kata Ithman muncul sembilan kali, yaitu dalam Q.S al-Baqarah [2]:182, Q.S Ali Imran [3]:178, Q.S al-Nisa [4]:20, Q.S alNisa [4]:48, Q.S al-Nisa [4]:50, Q.S al-Nisa [4]:111, Q.S al-Nisa [4]:112, Q.S al-Nisa [4]:112, Q.S al-Ma'idah [5]:107, kata athimun muncul enam kali yaitu dalam Q.S al-Baqarah [2]:276, Q.S al-Shu'ara [26]:222, Q.S alDukhan [44]:44, Q.S al-Janiyah [45]:7, Q.S alQalam [68]:12, Q.S al-Mutafifin [83]:12, kata Athiman muncul satu kali, yaitu dalam Q.S anNisa [4]:107, kata Athimun muncul satu kali dalam Q.S al-Baqarah [2]:283, kata Athiman muncul satu kali, yaitu dalm Q.S al-Insan [76]:24, dan kata Athimin muncul satu kali dalam Q.S al-Maidah [5]:106. ${ }^{11}$

\section{Analisis Kata Dhanb dan Ithm}

\footnotetext{
${ }^{10}$ Muhammad Fuad 'Abdul Baqi, Al-Mu'jam AlMufahras Li Alfaz Al Qur'an Al Karim, (Beirut:Dar Al Marefah, 2010) ,517-518.

${ }^{11}$ Muhammad Fuad 'Abdul Baqi, Al-Mu'jam AlMufahras Li Alfaz Al Qur'an Al Karim, 7, 51 \& 52.
}

\section{a. Kata Dhanb}

Al-Qur'an sangat sering menggunakan kata ini untuk menunjukkan perbuatan dosa yang sangat besar terhadap Tuhan. Yang dimaksudkan dosa disiniialah seperti dosa karena mendustakan ayat-ayat Allah, kufur, zalim, kemudian juga fasiq, kadhib dan lain sebagainya.

Selain itu, kata dhanbini merupakan penyebutan dosa bagi orang kafir, yang mana tertera jelas dalam al-Qur'an mengenai mereka yang menolak pada ayat-ayat Allah.

Berikut adalah ayat-ayatnya;

1) Kata Dhanb (dosa) yang berkenaan dengan kafir

Q.S al-Anfal [8]:52

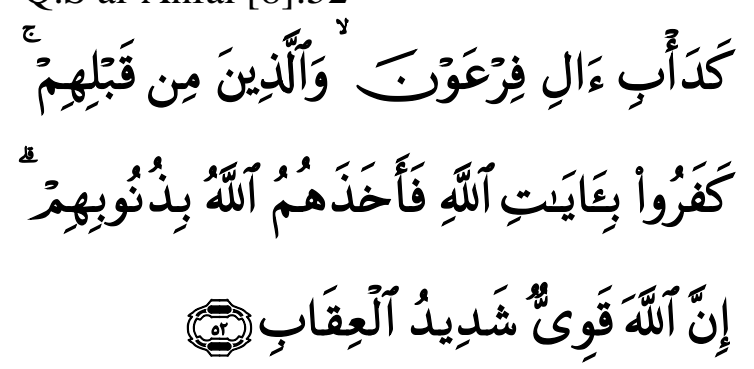

"Keadaan mereka) serupa dengan keadaan pengikut Fir'aun dan orangorang yang sebelum mereka. Mereka mengingkari ayat-ayat Allah, maka Allah menyiksa mereka disebabkan dosadosanya. Sungguh, Allah Mahakuat lagi sangat keras siksa-Nya."(Q.S al-Anfal [8]:52)

2) Kata Dhanb (dosa) yang berkenaan dengan takdhib

Q.S al-Anfal [8]:54
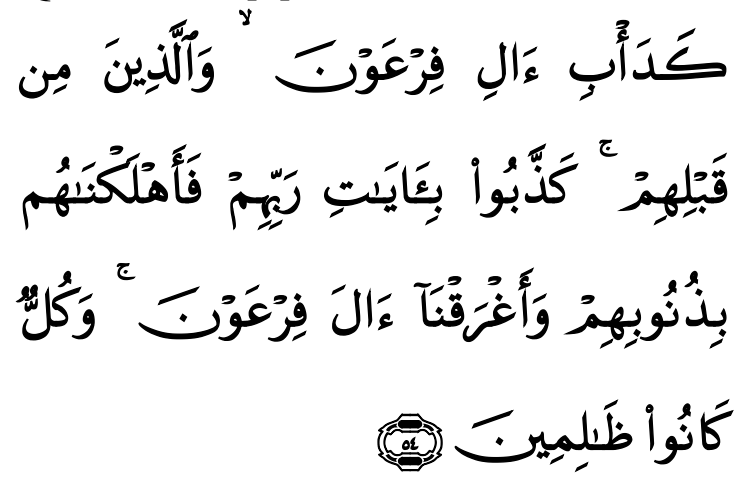

"(Keadaan mereka) serupa dengan keadaan pengikut Fir'aun dan orangorang yang sebelum mereka. Mereka mendustakan ayat-ayat Tuhannya, maka 
Dini Hasinatu Sa’adah, M.Solahudin, Dadang Darmawan

Kami membinasakan mereka disebabkan oleh dosa-dosanya dan Kami tenggelamkan Fir'aun dan pengikutpengikutnya; karena mereka adalah orang-orang yang zalim." (Q.S al-Anfal [8]:54).

3) Kata Dhanb (dosa) yang berkenaan dengan berpaling

Q.S al-Maidah [5]:49
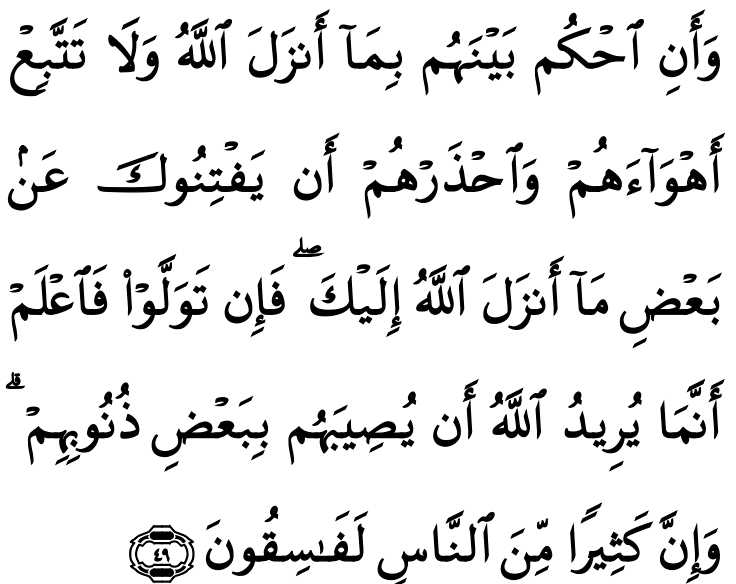

"Dan hendaklah kamu memutuskan perkara di antara mereka menurut apa yang diturunkan Allah, dan janganlah kamu mengikuti hawa nafsu mereka. Dan berhati-hatilah kamu terhadap mereka, supaya mereka tidak memalingkan kamu dari sebahagian apa yang telah diturunkan Allah kepadamu. Jika mereka berpaling (dari hukum yang telah diturunkan Allah), maka ketahuilah bahwa sesungguhnya Allah menghendaki akan menimpakan mushibah kepada mereka disebabkan sebahagian dosa-dosa mereka. Dan sesungguhnya kebanyakan manusia adalah orang-orang yang fasik."'(Q.S al-Maidah [5]:49).

4) Kata Dhanb (dosa) yang berkenaan dengan fahishah dan zalim

Q.S'Ali `Imran[3]:135
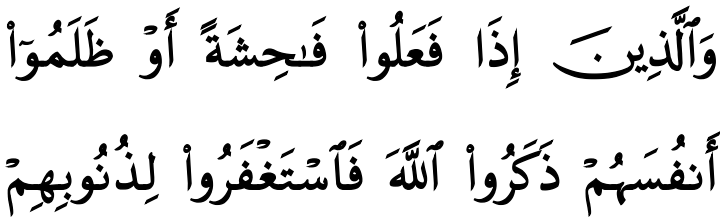

"Dan (juga) orang-orang yang apabila mengerjakan perbuatan keji atau menzalimi diri sendiri, (segera) mengingat Allah, lalu memohon ampunan atas dosa-dosanya, dan siapa (lagi) yang dapat mengampuni dosa-dosa selain Allah? Dan mereka tidak meneruskan perbuatan dosa itu, sedang mereka mengetahui." (Q.S 'Ali `Imran[3]:135).

5) Kata Dhanb (dosa) yang berkenaan dengan israf

Q.S al-Zumar[39]:53
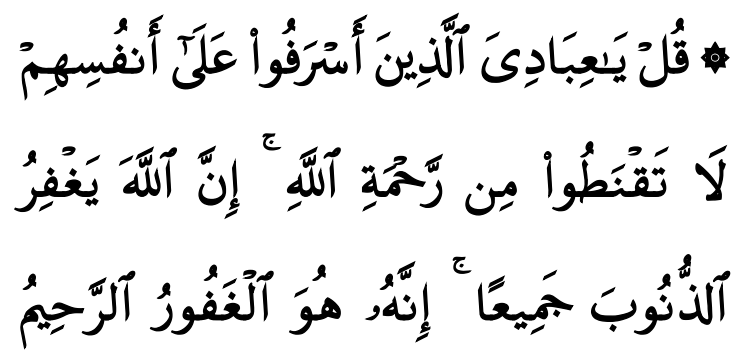

"Katakanlah, "Wahai hamba-hamba-Ku yang melampaui batas terhadap diri mereka sendiri! Janganlah kamu berputus asa dari rahmat Allah. Sesungguhnya Allah mengampuni dosa-dosa semuanya. Sungguh, Dialah Yang Maha Pengampun, Maha Penyayang”.(Q.S alZumar[39]:53).

6) Kata Dhanb (dosa) yang berkenaan dengan adhab atau iqab

Q.S Ali Imran [3]:11

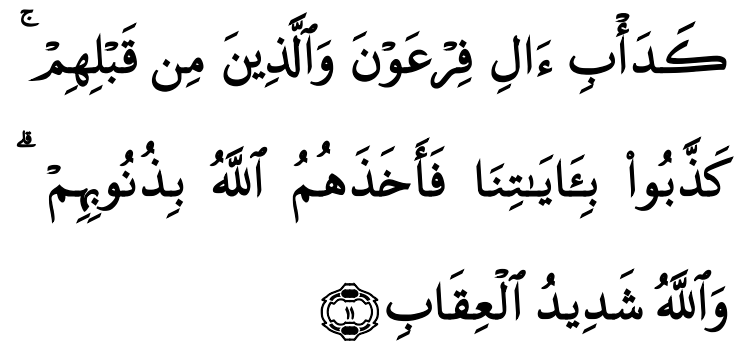

"(Keadaan mereka) seperti keadaan pengikut Fir'aun dan orang-orang yang 
Dini Hasinatu Sa'adah, M.Solahudin, Dadang Darmawan
Konsep Dhanb dan Ithm dalam Alquran (Studi Kajian Semantik Alquran) sebelum mereka. Mereka mendustakan ayat-ayat Kami, maka Allah menyiksa mereka disebabkan dosa-dosanya. Allah sangat berat hukuman-Nya."'(Q.S Ali Imran [3]:11).

7) Kata Dhanbyang berkenaan dengan ghafara

Q.S Ali Imran [3]:13-16
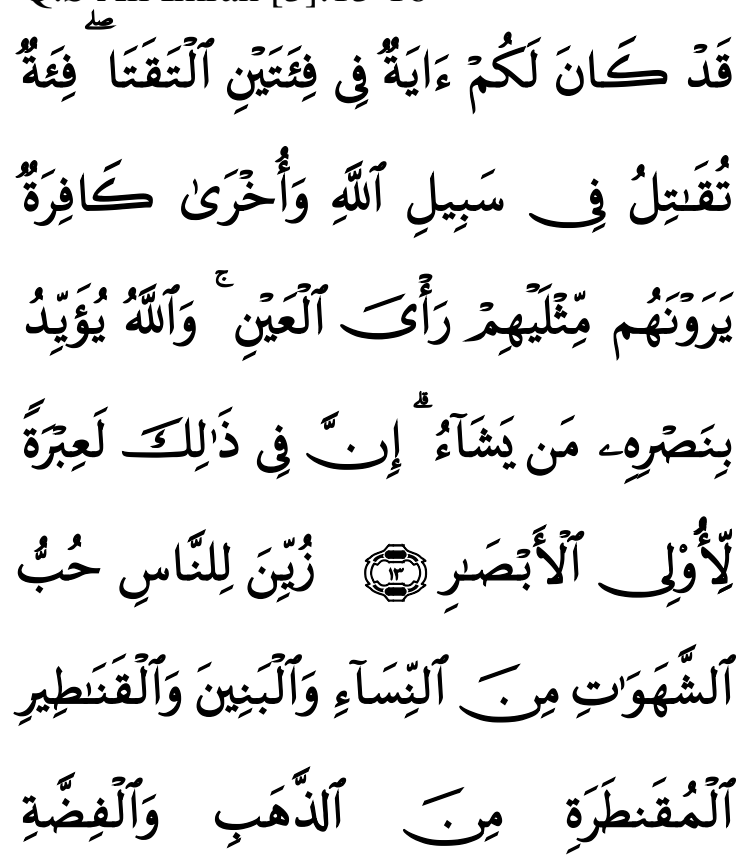

is

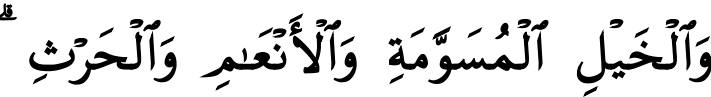

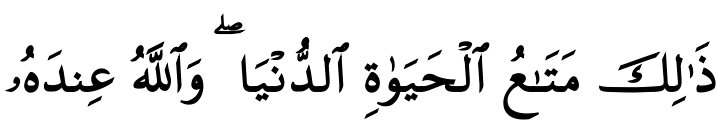
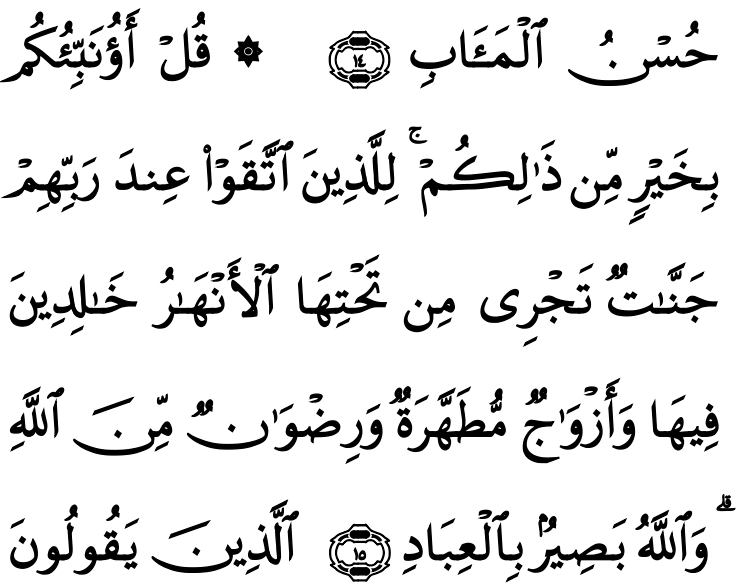

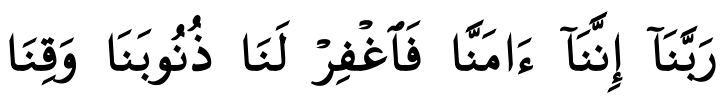

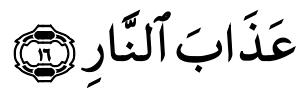

"Sesungguhnya telah ada tanda bagi kamu pada dua golongan yang telah bertemu (bertempur). Segolongan berperang di jalan Allah dan (segolongan) yang lain kafir yang dengan mata kepala melihat (seakan-akan) orang-orang muslimin dua kali jumlah mereka. Allah menguatkan dengan bantuan-Nya siapa yang dikehendakiNya. Sesungguhnya pada yang demikian itu terdapat pelajaran bagi orang-orang yang mempunyai mata hati. Dijadikan indah pada (pandangan) manusia kecintaan kepada apa-apa yang diingini, yaitu: wanita-wanita, anak-anak, harta yang banyak dari jenis emas, perak, kuda pilihan, binatang-binatang ternak dan sawah ladang. Itulah kesenangan hidup di dunia, dan di sisi Allah-lah tempat kembali yang baik (surga). Katakanlah: "Inginkah aku kabarkan kepadamu apa yang lebih baik dari yang demikian itu?". Untuk orang-orang yang bertakwa (kepada Allah), pada sisi Tuhan mereka ada surga yang mengalir dibawahnya sungai-sungai; mereka kekal didalamnya. Dan (mereka dikaruniai) isteri-isteri yang disucikan serta keridhaan Allah. Dan Allah Maha Melihat akan hamba-hambaNya. (Yaitu) orang-orang yang berdoa: Ya Tuhan kami, sesungguhnya kami telah beriman, maka ampunilah segala dosa kami dan peliharalah kami dari siksa neraka," (Q.S Ali Imran [3]:13-16).

8) Kata dhanb berkenaan dengan taubah

$$
\text { Q.S Al-Taubah[9]:102 }
$$

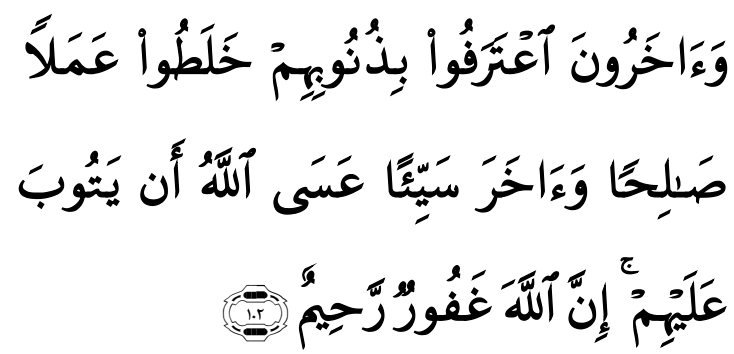

"Dan (ada pula) orang lain yang mengakui dosa-dosa mereka, mereka mencampuradukkan pekerjaan yang baik dengan pekerjaan lain yang buruk. 
Dini Hasinatu Sa'adah, M.Solahudin, Dadang Darmawan

Mudah-mudahan Allah menerima tobat mereka. Sesungguhnya Allah Maha Pengampun, Maha Penyayang”.'(Q.S AlTaubah[9]:102)

Setelah dianalisa kata dhanb dari ayatayat diatas, maka dapat disimpulkan sebagai berikut;

\begin{tabular}{|c|c|c|}
\hline 1. & Sebab & 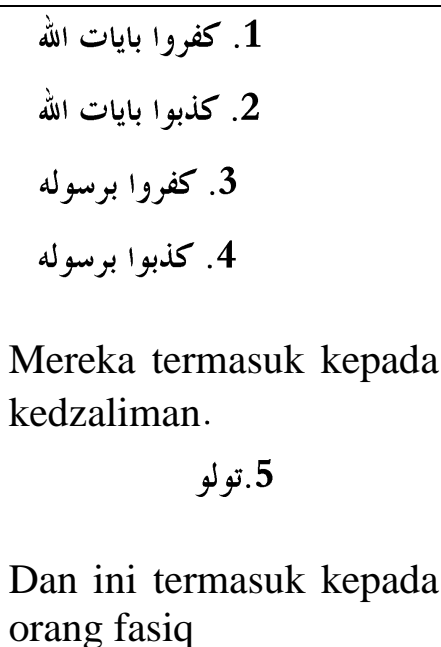 \\
\hline 2. & Bentuk & 3 1. 1. فلملوا فاحشة اسرفوا انفسهم انفسهم \\
\hline 3. & Akibat & 2. 1 1. عذاب(حاصب, غرق, النار \\
\hline 4. & $\begin{array}{c}\text { Pengha } \\
\text { pusan }\end{array}$ & 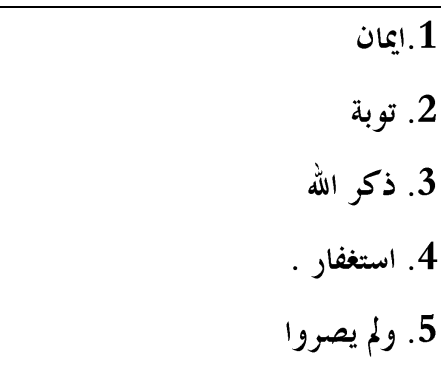 \\
\hline
\end{tabular}

Table 1

Dari penjelasan diatas, dapat dipahami bahwa dhanb itu adalah perbuatan orang yang tidak menerima ayat-ayat Allah, baik menolaknya itu melalui Rasul atau melalui siapapun, dari yang mereka lakukan akan mengakibatkan ganjaran sesuai yang mereka perbuat, yaitu berupa siksaan atau masuk ke dalam neraka. Namun, dosa yang diperbuat
Konsep Dhanb dan Ithm dalam Alquran (Studi Kajian Semantik Alquran)

oleh mereka akan dapat dihapuskan apabila mereka beriman kepada Allah, meminta ampunan kepada Allah, taubat, dan menerima pada ayat-ayat Allah.

\section{b. Kata Ithm}

Kata ithm diartikan sebagai dosa, namun mengenai pengertian pokok dari kata ini berbeda pendapat, Muhit - al-Muhit misalnya, beliau mendefinisikannya yaitu sebagai pelanggaran terhadap sesuatu yang haram, yang mana melakukan sesuatu yang melanggar hukum. ${ }^{12}$

Bila dilihat dari ayat-ayat yang berkaitan dengan ithm, lafadz tersebut memang diperuntukkan bagi perbuatan yang sudah jelas diharamkan, seperti memakan bangkai, darah, meminum khamr,dan itu termasuk kepada ithm kabir, sedangkan syirk termasuk pada ithm 'azim. Kemudian lafadz ithm ini bergandengannya itu dengan lafadz,fawahish, zann,ma'siah, mengubah wasiat, menyembunyikan saksi, dan lain sebagainya, berikut adalah ayat-ayatnya;

1) Kata ithm yang berkenaan dengan syirk

Q.S al-Nisa [4]:48

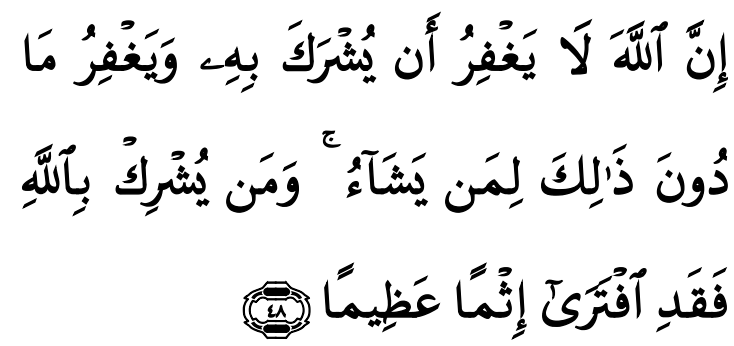

"Sesungguhnya Allah tidak akan mengampuni dosa syirik, dan Dia mengampuni segala dosa yang selain dari (syirik) itu, bagi siapa yang dikehendakiNya. Barangsiapa yang mempersekutukan Allah, maka sungguh ia telah berbuat dosa yang besar".(Q.S al-Nisa [4]:48).

2) Kata ithm berkenaan dengan " $m a$ 'siah kepada Rasul"

Q.S Al-Mujadila[58]:8 
Konsep Dhanb dan Ithm dalam Alquran (Studi Kajian Semantik Alquran)

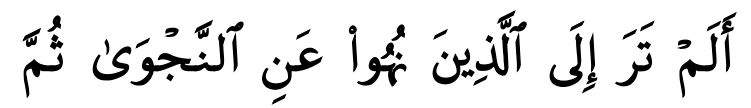

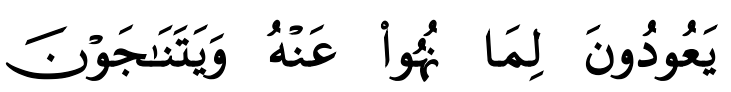

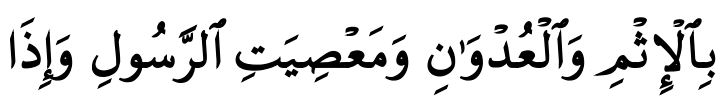

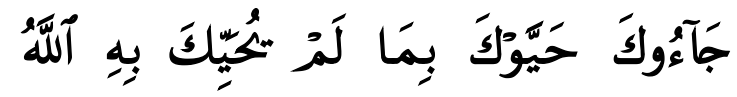

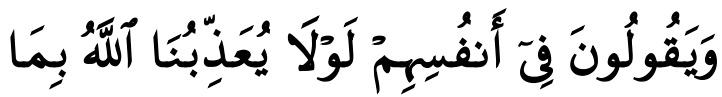

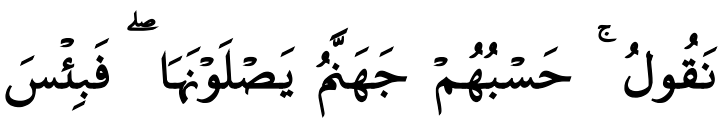
آلْمَصِيرُ

"Tidakkah engkau perhatikan orangorang yang telah dilarang mengadakan pembicaraan rahasia, kemudian mereka kembali (mengerjakan) larangan itu dan mereka mengadakan pembicaraan rahasia untuk berbuat dosa, permusuhan dan durhaka kepada Rasul. Dan apabila mereka datang kepadamu (Muhammad), mereka mengucapkan salam dengan cara yang bukan seperti yang ditentukan Allah untukmu. Dan mereka mengatakan pada diri mereka sendiri, "Mengapa Allah tidak menyiksa kita atas apa yang kita katakan itu?" Cukuplah bagi mereka neraka Jahanam yang akan mereka masuki. Maka neraka itu seburuk-buruk tempat kembali”.(Q.S Al-Mujadila[58]:8).

3) Kata ithm berkenaan dengan mengubah wasiat

Q.S al-Baqarah [2]: (180-182)

كُتِبَ عَلَيْكُمْ إِذَا حَضَرَرَ أَحَدَكُمُ آَلْمَوْتُ إِن

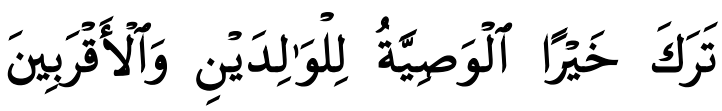

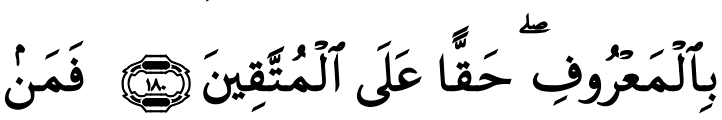

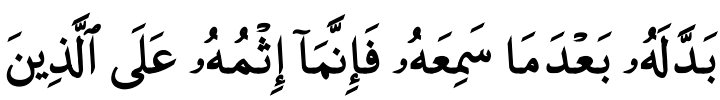

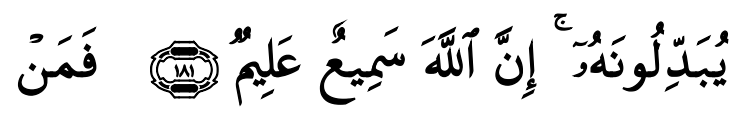
خَافَ مِن مُوصِِ جَنَفًا أَوْ إِتْمَا فَأَصْلَحَ

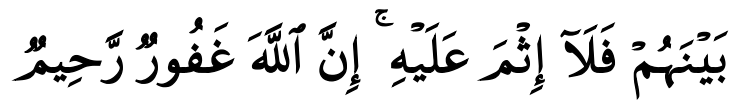

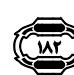

"Diwajibkan atas kamu, apabila seorang di antara kamu kedatangan (tanda-tanda) maut, jika ia meninggalkan harta yang banyak, berwasiat untuk ibu-bapak dan karib kerabatnya secara ma'ruf, (ini adalah) kewajiban atas orang-orang yang bertakwa. Maka barangsiapa yang mengubah wasiat itu, setelah ia mendengarnya, maka sesungguhnya dosanya adalah bagi orang-orang yang mengubahnya. Sesungguhnya Allah Maha Mendengar lagi Maha Mengetahui. (Akan tetapi) barangsiapa khawatir terhadap orang yang berwasiat itu, berlaku berat sebelah atau berbuat dosa, lalu ia mendamaikan antara mereka, maka tidaklah ada dosa baginya. Sesungguhnya Allah Maha Pengampun lagi Maha Penyayang”.(Q.S al-Baqarah [2]:180182).

4) Kata ithm berkenaan dengan menyembunyikan kesaksian Q.S Al-Baqarah[2]:283

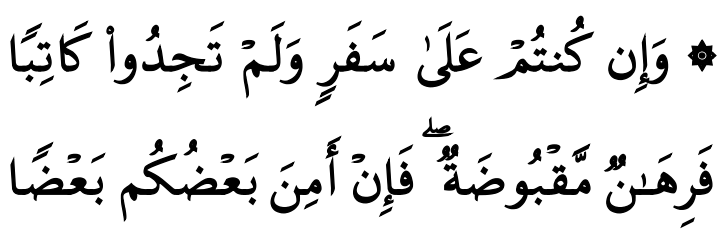

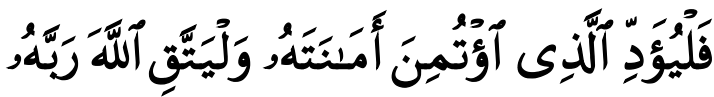

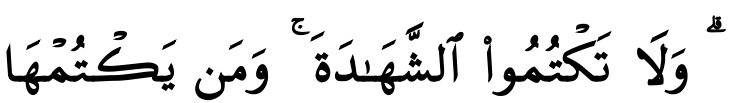

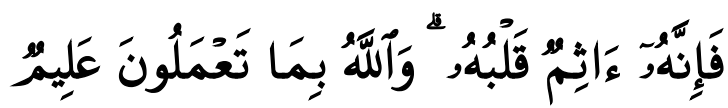


Dini Hasinatu Sa’adah, M.Solahudin, Dadang Darmawan

"Dan jika kamu dalam perjalanan sedang kamu tidak mendapatkan seorang penulis, maka hendaklah ada barang jaminan yang dipegang. Tetapi, jika sebagian kamu mempercayai sebagian yang lain, hendaklah yang dipercayai itu menunaikan amanatnya (utangnya) dan hendaklah dia bertakwa kepada Allah, Tuhannya. Dan janganlah kamu menyembunyikan kesaksian, karena barangsiapa menyembunyikannya, sungguh, hatinya kotor (berdosa). Allah Maha Mengetahui apa yang kamu kerjakan”.(Q.S al-Baqarah [2]:283).

5) Kata ithm berkenaan denganharamdan suht

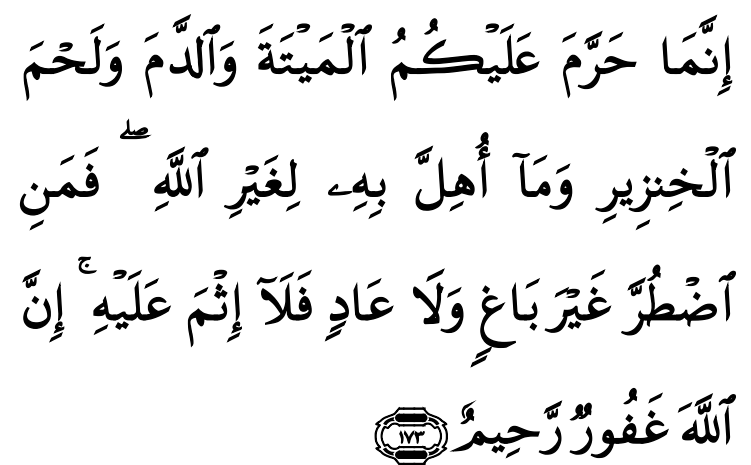

"Sesungguhnya Allah hanya mengharamkan bagimu bangkai, darah, daging babi, dan binatang yang (ketika disembelih) disebut (nama) selain Allah .Tetapi barangsiapa dalam keadaan terpaksa (memakannya) sedang dia tidak menginginkannya dan tidak (pula) melampaui batas, maka tidak ada dosa baginya. Sesungguhnya Allah Maha Pengampun lagi Maha Penyayang”.(Q.S al-Baqarah[2]:173).

6) Kata ithm berkenaan dengan $\mathrm{kufr}$ Q.S Ali Imran [3]:178

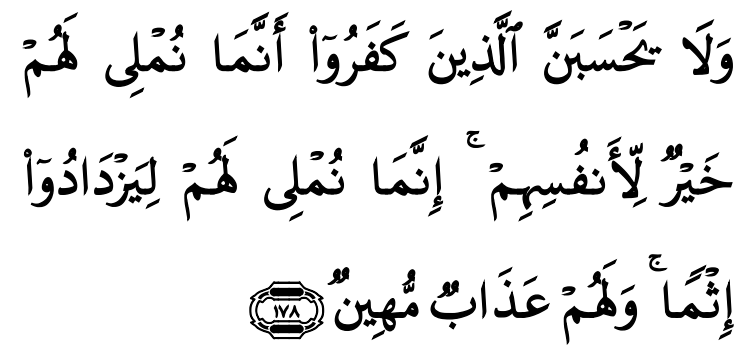

"Dan janganlah sekali-kali orang-orang kafir menyangka, bahwa pemberian
Konsep Dhanb dan Ithm dalam Alquran (Studi Kajian Semantik Alquran) tangguh Kami kepada mereka adalah lebih baik bagi mereka.Sesungguhnya Kami memberi tangguh kepada mereka hanyalah supaya bertambah-tambah dosa mereka; dan bagi mereka azab yang menghinakan".(Q.S Ali Imran [3]:178).

7) Kata ithm berkenaan dengan membawa berita bohong

Q.S al-Nur[24]:11

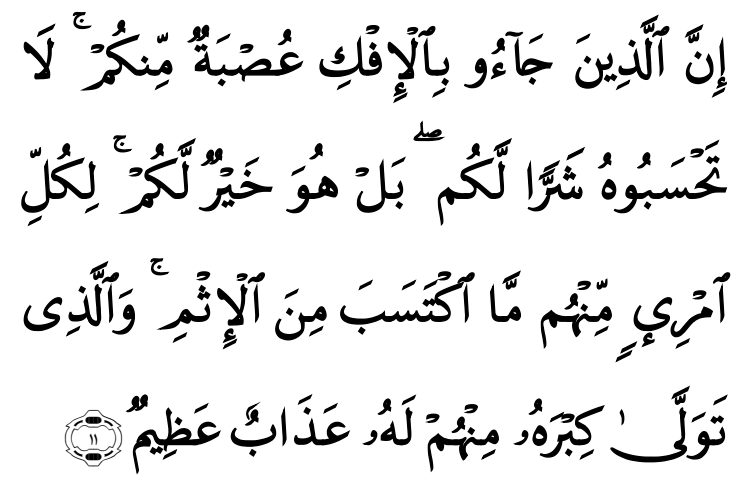

"Sesungguhnya orang-orang yang membawa berita bohong itu adalah dari golongan kamu (juga).Janganlah kamu mengira berita itu buruk bagi kamu bahkan itu baik bagi kamu. Setiap orang dari mereka akan mendapat balasan dari dosa yang diperbuatnya. Dan barangsiapa di antara mereka yang mengambil bagian terbesar (dari dosa yang diperbuatnya), dia mendapat azab yang besar (pula)".(Q.S al-Nur[24]:11)

8) Kata ithm berkenaan dengan berprasangka

Q.S al-Hujurat[49]:12

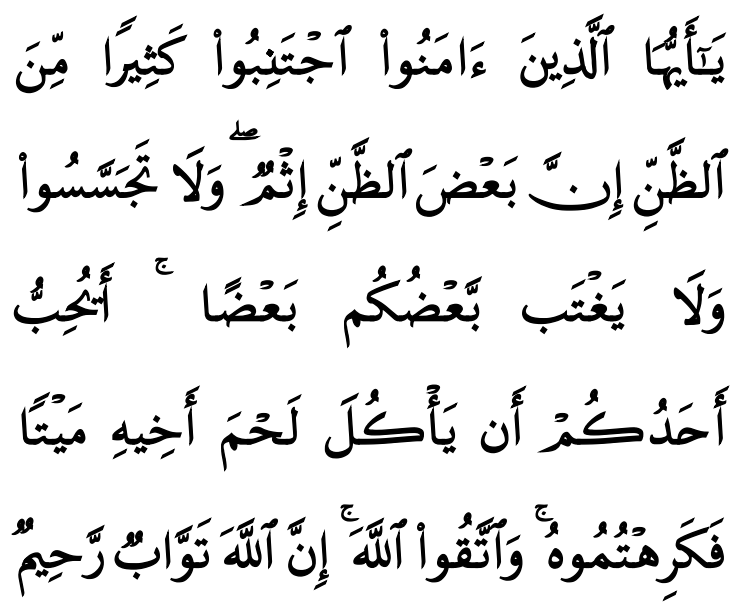


Dini Hasinatu Sa’adah, M.Solahudin, Dadang Darmawan

"Wahai orang-orang yang beriman! Jauhilah banyak dari prasangka, sesungguhnya sebagian prasangka itu dosa dan janganlah kamu mencari-cari kesalahan orang lain dan janganlah ada di antara kamu yang menggunjing sebagian yang lain. Apakah ada di antara kamu yang suka memakan daging saudaranya yang sudah mati?Tentu kamu merasa jijik. Dan bertakwalah kepada Allah, sesungguhnya Allah Maha Penerima tobat, Maha Penyayang”.(Q.S Al-Hujurat[49]:12).

9) Kata ithm berkenaan dengan fawahish Q.S Al-Najm[53]:32

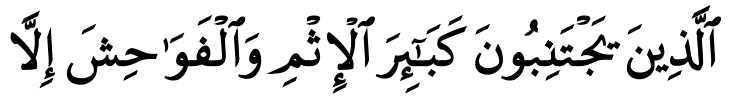

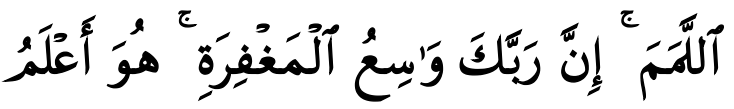

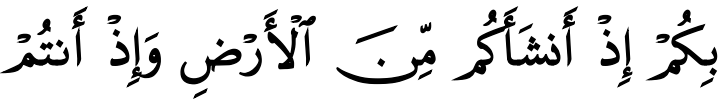

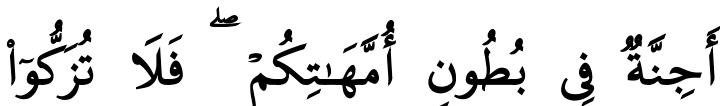

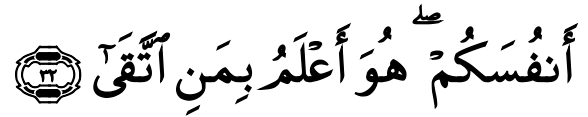

"(Yaitu) mereka yang menjauhi dosa-dosa besar dan perbuatan keji, kecuali kesalahan-kesalahan kecil. Sungguh, Tuhanmu Mahaluas ampunan-Nya.Dia mengetahui tentang kamu, sejak Dia menjadikan kamu dari tanah lalu ketika kamu masih janin dalam perut ibumu.Maka janganlah kamu menganggap dirimu suci.Dia mengetahui tentang orang yang bertakwa".(Q.S AlNajm[53]:32)

10) Kata ithm berkenaan dengan' $a z a b$ Q.S Al-Baqarah[2]:85

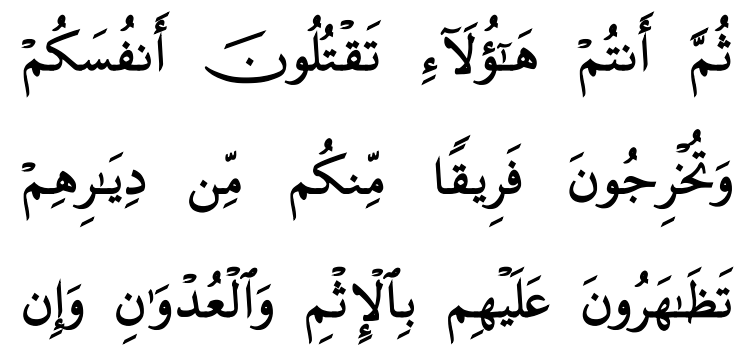

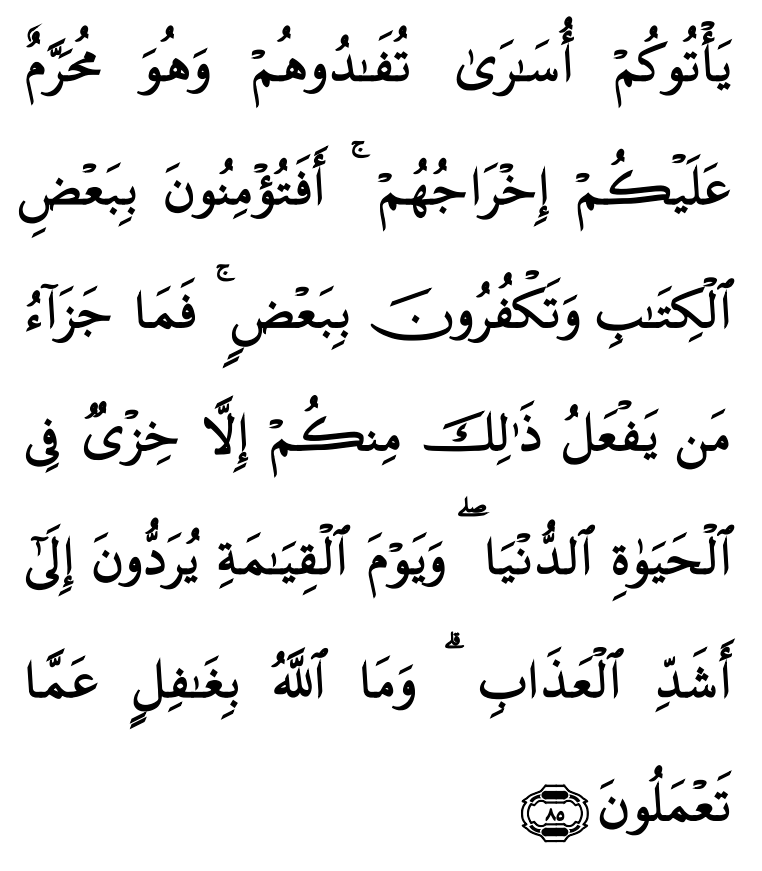

"Kemudian kamu (Bani Israil) membunuh dirimu (sesamamu), dan mengusir segolongan dari kamu dari kampung halamannya. Kamu saling membantu (menghadapi) mereka dalam kejahatan dan permusuhan.Dan jika mereka datang kepadamu sebagai tawanan, kamu tebus mereka, padahal kamu dilarang mengusir mereka. Apakah kamu beriman kepada sebagian Kitab (Taurat) dan ingkar kepada sebagian (yang lain)? Maka tidak ada balasan (yang pantas) bagi orang yang berbuat demikian di antara kamu selain kenistaan dalam kehidupan dunia, dan pada hari Kiamat mereka dikembalikan kepada azab yang paling berat. Dan Allah tidak lengah terhadap apa yang kamu kerjakan”.(Q.S AlBaqarah[2]:85).

Setelah dianalisa kata dhanb dari ayatayat diatas, maka dapat disimpulkan sebagai berikut;

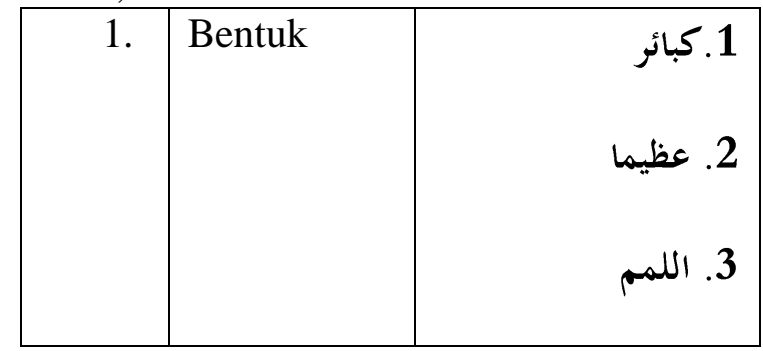


Dini Hasinatu Sa'adah, M.Solahudin, Dadang Darmawan

\begin{tabular}{|c|c|c|}
\hline 2. & Sebab & 2. 1.الشرك \\
\hline 3. & $\begin{array}{l}\text { Macam- } \\
\text { macam }\end{array}$ & $\begin{array}{l}\text { 1. Perbuatan } \\
\text { keji } \\
\text { 2. Menuduh } \\
\text { zina } \\
\text { 3. Memakan } \\
\text { makanan } \\
\text { yang } \\
\text { haram } \\
\text { 4. Menyemb } \\
\text { unyikan } \\
\text { kesaksian } \\
\text { Merubah } \\
\text { wasiat } \\
\text { 6. Berprasan } \\
\text { gka } \\
\text { 7. Membawa } \\
\text { berita } \\
\text { bohong }\end{array}$ \\
\hline 4. & Akibat & $\begin{array}{l}\text { 1. Siksa } \\
\text { 2. Hukuman } \\
\text { 3. Neraka } \\
\text { jahannam }\end{array}$ \\
\hline 5. & $\begin{array}{l}\text { pembersiha } \\
n\end{array}$ & $\begin{array}{l}\text { 1. Taqwa } \\
\text { 2. Istighfar }\end{array}$ \\
\hline
\end{tabular}

Table 2

Dari penjelasan diatas, dapat dipahami bahwa ithm itu adalah perbuatan orang yang beriman, yang mana mereka sedang melakukan perbuatan lalai, melanggar peraturan Allah, baik itu melanggar karena memakan makanan yang haram, melakukan perbuatan keji, dan mereka yang hanya
Konsep Dhanb dan Ithm dalam Alquran (Studi Kajian Semantik Alquran)

mengaku beriman kepada Allah pada ucapannya, sedangkan dalam hatinya dan perbuatannya itu mereka melanggar aturan Allah atau dapat digolongkan kepada orang munafik.

\section{Analisis Medan Semantik \\ a. Medan Semantik kata Dhanb}

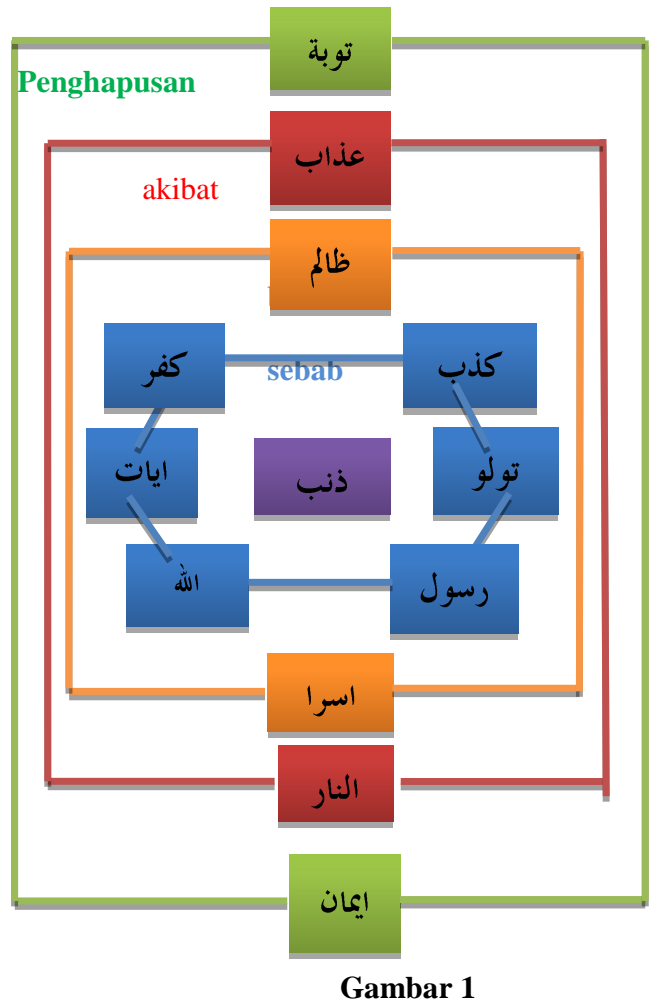

Gambar diatas merupakan medan semantik daribeberapa ayat tentang sebab perbuatan dhanb dan akibatnya. Makna relasional sebagai sebab perbuatan dosa tersebut dapat dilihat ketika disandingkan dengan kata, kadhib, kafir, tawallau, fasiq.Kemudian bentuknya itu dapat dilihat ketika disandingkan dengan israf, fahishah, zalim ,dan akibat dari perbuatannya itu dapat dilihat ketika disandingkan dengan kata 'azab, 'iqab dan al-Nar.

Semua perbuatan dosa (dhanb) yang dilakukan itu akan diampuni Allah SWT apabila meminta ampunan kepada-Nya, dianatara cara pembersihan dosa tersebut yaitu dengan cara beriman kepada Allah, menerima pada ayat-ayat Allah, bertaubat, meminta ampunan kepada Allah, dan tidak mengulangi perbuatan dosa. 


\section{b. Medan Semantik kata Ithm}

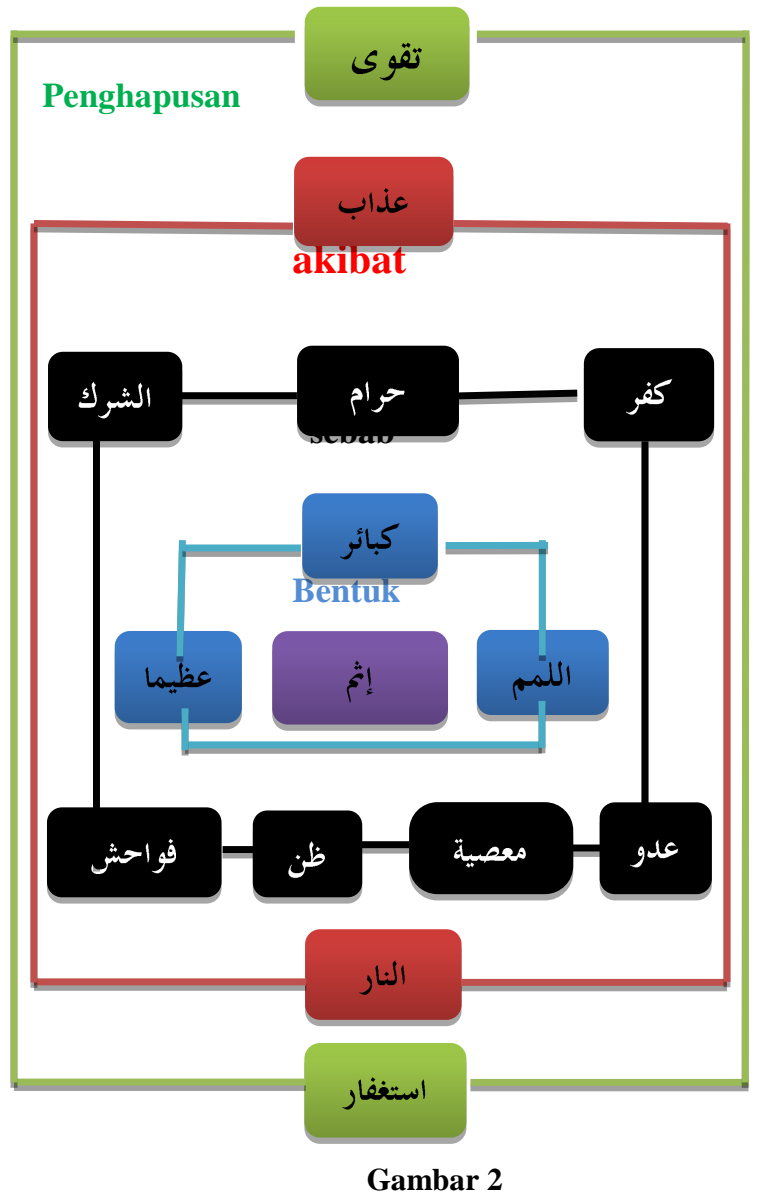

Gambar di atas merupakan medan semantik dari beberapa ayat tentang ithm,berupa sebabnya misalnya memakan makanan yang diharamkan ketika disandingkan dengan kata haram,berbuat keji ketika bersandingan dengan fawahish, menyekutukan Allah ketika bersandingan dengan as-Syirk, kemudian dalam hal akibatnya dapat dilihat ketika bersandingan dengan kata 'adzab, al-Nar.

\section{Konsep Dosa dalam al-Qur'an}

Al-Qur'an telah menjelaskan berbagai macam bentuk dosa, baik dari segi macammacamnya, segi sebab-sebanya, maupun dari akibatnya. Dhanb danithm adalah dua kata yang bermakna dosa, namun keduanya memiliki perbedaan ketika sudah dikorelasikan dengan lafadz yang lain.
Konsep Dhanb dan Ithm dalam Alquran (Studi Kajian Semantik Alquran)

Setelah dianalisis dengan medan semantiknya, dhanb merupakan dosa yang masih umum, baik itu kepada Allah maupun kepada manusia, tidak ada penyebutan dhanb kabir atau dhanb 'azim. Kata dhanb ini bersandingan dengan kata kufr, israf, fahishah, zalim, dan yang lainnya yang sudah disebutkan sebelumnya.

Sedangkan kata ithm, merupakan dosa besar yang sudah jelas diharamkannya, kemudian ithm ini pun ada ithm kabir dan ada ithm 'azim. Ithm kabir itu seperti meminum khamr, memakan makanan yang haram seperti bangkai, darah, daging babi, kemudian kufr,judi,. menyembelih hewan dengan tanpa menyebut nama Allah, dan yang lainnya yang sudah disebutkan sebelumnya. Sedangkan ithm 'azim itu berupa dosa karena menyekutukan Allah (syirk).

Dosa dan kesalahan merupakan masalah penting dalam Islam, karenakeduanya menyangkut hubungan baik antara manusia dengan Allah, denganmasyarakat dan lingkungannya serta dengan dirinya sendiri. Ketenteraman, kesejahteraan dan kebahagiaan manusia banyak ditentukan oleh seberapa jauh ia terhindar atau bersih dari dosa dan kesalahan, ataupun sampai seberapa banyak ketaatan dan kebaikan yang diperbuatnya.

Sebaliknya penderitaan kesengsaraan dan ketidak bahagiaan manusia banyak pula ditentukan oleh seberapa banyak dosa dan kesalahan yang telah dilakukannya. Orangorang yang berbuat dosa dan kesalahan diancam Allah dengan hukuman berat, baik di dunia maupun di akhirat.Sebaliknya orang yang berbuat taat dan kebaikan dijanjikan dan diberikan Allah pahala yang besar, baik di dunia maupun di akhirat. ${ }^{13}$

Menurut Imam Ghazali, bahwa dosa menurut sifat dasarnya dapat dibagi atas tiga bagian. Pertama yang berhubungan dengan sifat manusiadan terdiri atas empat sifat, yaitu sifat rububiyah, syaithaniyah, bahimiyah dan subu'iyah. Kedua berhubungan dengan obyeknya dapat pula dibagi atas tiga, yaitu

${ }^{13}$ Yahya Jaya, Peranan Taubat dan Maaf Dalam Kesehatan Mental, (Bandung: RemajaRosdakarya, 1995), 30-35 
dosa antara manusia dengan Allah, dosa yang berhubungan dengan hak-hak masyarakat dan lingkungan, dan dosa yang berhubungan dengan diri manusia sendiri. Dan ketiga dosa ditinjau dari segi bahaya dan mudaratnya terdiri pula atas dua, yaitu dosa kecil dan dosa besar. $^{14}$

\section{SIMPULAN}

Dari penjelasan mengenai analisis kata dhanb dan ithm dalam al-Qur'an,maka dapat ditarik beberapa kesimpulan:

1. Kata dhanb muncul dalam alQur'an sebanyak 37 kali, yang termuat dalam 26 surat, sedangkan kata ithm muncul dalam al-Qur'an sebanyak 32 kali, yang termuat dalam 20 surat.

2. Kata dhanb menurut kamus bahasa Arab memiliki makna dosa atau kesalahan, sedangkan kata ithm menurut kamus bahasa Arab memiliki makna perbuatan yang tidak halal.

3. Kata dhanb dijelaskan dalam tafsir Ibn Katsir dan al-Maraghi memiliki adalah dosa nya orang kafir, sedangkan kata ithm dalam kedua tafsir tersebut dijelaskan bahwa ithm adalah dosa nya orang munafik.

4. Kata dhanb bila dilihat dengan medan semantiknya selalu bersandingan dengan kata kufr, kadhab, tawallaw, israf, zalim, al-Nar, adhab, taubah, iman, dhikrullah, dan istighfar, sedangkan kata ithm selalu bersandingan dengan kata shirk, fawahish, zann, haram, kufr, 'aduww, kaba'ir, 'azim, al-Lamm, taqwa, istighfar, 'adhab dan alNar.

5. Kata dhanb dan ithm setelah dianalisa dengan medan semantiknya memiliki beberapa poin, yang pertama yaitu mengenai sebab, sebab dari dhanb diantaranya adalah kufr, kadhab, tawallaw, sedangkan sebab ithm diantaranya ialah shirk, fawahish, zann, haram, kufr, dan ' $a d u w w$, poin kedua mengenai bentuk, bentuk dhanb diantaranya ialah israf, zalim, dan fahishah, sedangkan bentuk dari

${ }^{14}$ Hasbullah Bakry, Pedoman Islam di Indonesia, (Jakarta: UI Press, 1988), 29. ithm adalah kaba'ir, 'azim, dan al-Lamam, kemudian poin ketiga ialah mengenai akibat, akibat dari dhanb dan ithm adalah $a d h a b$ dan al-Nar, dan yang terakhr mengenai penghapusan, pengahapusan dari dhanb adalah taubah, iman, dhikrullah, dan istighfar, sedangkan pengahapusan dari perbuatan ithm adalah taqwa, dan istighfar.

6. Kata dhanb dan ithm dapat dikategorisasikan menjadi dua sesuai dengan teorinya Toshihiko Izutu yaitu makna dasar dan makna relasional. Makna dasar dari kata dhanb ialah dosa atau kesalahan, sedangkan makna relasional nya ialah dosa orang kafir yang mana mereka berpaling dari ayat-ayat Allah, mendustakan ayat-ayat Allah, kemudian makna dasar dari kata ithm adalah perbuatan yang tidak halal, sedangkan makna relasional nya ialah perbuatan dosa orang munafik, yang mana mereka mengaku beriman pada mulutnya, tetapi pada sikap dan perbuatan mereka tidak mencerminkan orang yang beriman.

7. Kata dhanb menurut semantik al-Qur'an ialah dosa orang kafir yang disebabkan mereka berpaling dari ayat-ayat Allah dan mendustakan ayat-ayat Allah, sedangkan kata ithm menurut semantik al-Qur'an ialah dosa orang munafik yang disebabkan mereka hanya mengaku beriman kepada Allah pada mulutnya saja, tetapi perbuatan mereka melanggar dari aturan-aturan Allah.

Demikianlahbeberapa kesimpulan yang dapat penulis kemukakan.

\section{DAFTAR PUSTAKA}

Abi al-Fadhl Jamaluddin, Al-Allamah. Muhammad bin Mukarram ibn Mandzur al-Ifriqi al-Mishri, Lisan alArab, Beirut: Daar as-Shadir, 1355. Aminuddin.Semantik Pengantar Studi Tentang Makna, Bandung: Sinar Baru Algensindo, 2015.

Al-Qattan, Manna Khalil.Studi Ilmu-ilmu 
Dini Hasinatu Sa'adah, M.Solahudin, Dadang

Darmawan

Qur'an, Bogor:Pustaka Litera AntarNusa, 2012.

Bakry,Hasbullah.Pedoman Islam di Indonesia ,Jakarta: UI Press, 1988.

Fuad 'Abdul Baqi, Muhammad. AlMu'jam Al-Mufahras Li Alfaz Al Qur'an Al Karim, Beirut:Dar Al Marefah, 2010.

Izutsu, Toshihiko.Relasi Tuhan dan Manusia,Yogyakarta: PT Tiara Wacana Yogya, 2003.
Konsep Dhanb dan Ithm dalam Alquran (Studi Kajian Semantik Alquran)

. Etika Beragama dalam alQur'an,Jakarta:Pustaka Firdaus, 1995.

Jaya,Yahya.Peranan Taubat dan Maaf Dalam Kesehatan Mental, Bandung: RemajaRosdakarya, 1995.

Warson Munawwir, Ahmad. Kamus alMunawwir

Arab-Indonesia Terlengkap, Surabaya: Penerbit Pustaka Progressif, 1997. 